\title{
The Analysis of Constructions in the Evaluation Activity
}

\author{
Mihaela-Cristina Onica \\ mihaela.onica@ugal.ro \\ Gianita Bleoju \\ gianitab@yahoo.com \\ Dunarea de Jos University of Galati, Romania
}

\begin{abstract}
The estimation of value through the cost method is based on comparison, and namely the construction cost of a propriety is compared to the value of an existing propriety or to a similar one that is being built. The method reflects the fact that the participants on the market recognize a relation between value and cost, it is important for the estimation of the market value of new or relatively new buildings as, in this cases, the cost and the market value are usually relatively close. New or relatively new constructions represent the best usage of the terrain. Replacement cost is the estimated cost for building, given the current prices at the moment of the evaluation of a building with an equivalent utility to the one of the evaluated building.
\end{abstract}

Keywords: cost method, the estimation of the market value, the estimation of the constructions depreciation

JEL Classification: G32; G33; C39

\section{Introduction}

In order to reach the estimated value through the cost method, we must pass over the following stages:

* The estimation of the value of the terrain considering that it is free and available for the best usage;

* The estimation of the total reconstruction or replacement cost of the constructions at the moment of the evaluation;

* The estimation of the constructions depreciation;

* The removal of the cumulated depreciation from the total reconstruction or replacement cost in order to reach to net cost;

* The adding of the terrain's value in order to reach the total value of the real estate propriety.

The principle which stands at the basis of the constructions' evaluation consists of:

* The setting of the new construction's value (the replacement or the reconstruction value);

* The estimation of the cumulated depreciation.

1. The replacement cost

The setting of the new construction's value aims at setting the reconstruction costor the replacement cost. The reconstruction cost is the estimated cost of building, given the prices at the data of the evaluation, a copy, an accurate reproduction of the evaluated building, using the same materials, the construction standards, architecture, plans, quality, labor and including all the deficiencies, the oversizing and the depreciation of the evaluated building.

The replacement cost is the estimated cost in order to build, at the prices at the evaluation data of a building with equivalent utility to the one of the evaluated building, by using modern materials, standards, architecture and updated plans. Three cost estimation methods are known:

- The replacement costs method;

- The segregated costs method;

- The currencies method;

The estimation of the cumulated depreciation - depreciation is a loss of value of the real estate propriety compared to the reconstruction or the replacement cost of the building, which 
can result from physical, functional or external causes. The estimation methods of depreciation are:

- The economic life method;

- The modified economic life method;

- The comparison method.

\section{The estimation of the replacement value of the building. The replacement Costs' Value Method}

The estimation of the market value through the cost method is based on the comparison between the construction cost of a propriety and the existing value of the propriety. The method reflects the fact that the participants on the market admit the relation between the cost and the value.

The substitution principle is fundamental to the cost method, showing that no prudent buyer would pay for a real estate propriety no more than the needed cost in order the gain the immediate ownership of a surface and build proprieties with similar utilities, destinations and attractiveness.

The main estimation method is the "unitary cost method", based on the reevaluation catalogues issued in 1965 by the Central Committee for Fixed Funds Inventory.

The method uses unitary prices and the correction coefficients provided by these catalogues, according to the technical-construction features regarding the inventory compared to the standard ones.

The scale prices consider the generic dimensions of the object, its usage, the individual features, the normal and special inventory. The accuracy of the reached value is conditioned by the accuracy through which the "model" (the copy) corresponds to the real situation of the building.

According to the "replacement value method", the remaining value of the buildings is evaluated as an adjusted unitary replacement value of the surface, depreciated by the evaluated attrition, which can be foreseen.

The unitary replacement value is evaluated through the actualization of a basic corrected (catalogue) value, through a methodology approved by the MLPAT Order no. 32/1995. Both the basic value and the actualization coefficients present the following official sources:

- Catalogues for inventory and reevaluation of the fixed assets (1965 prices)

- Actualization indexes set recommended by INCERC and the Technical Experts' Committee

In the current Report, the unitary replacement value has been established through the usage of the scale prices and the corrections in Catalogues no. 124/ file 4B and no 124/ file 11.

The total replacement value (for the whole surface) is updated using a coefficient (correlated to the application field in the used catalogue) set by the CET and published in the "Expertizatehnica" no 94/ November 2005 periodical and is corrected using the total estimated cumulated depreciation.

Depreciation represents the loss of value reported to the replacement/reconstruction cost due to some physical, functional, external causes. Theoretically, depreciation can begin accumulating from the finalization of the building, even if it represents "the best usage".

Depreciation represents the difference between the reconstruction or replacement cost of the construction (building) and the market value.

The estimation of the depreciation is made using the segregation method, which assumes the separated analysis of each cause of depreciation.

The evaluation through the "replacement value method" was made for a catalogue model with the following features:

Height regime - ground floor, with wall of bricks, with a $33 \mathrm{~cm}$ high socket, wooden framing, tile roofing, wooden floors, average finish level;

The calculation of the replacement value at the level of 01.01.1965 


\section{THE HOUSE}

$\operatorname{Ad}=208,89 \mathrm{~m}^{2}$

Unitary value (catalogue 124/file nr. 4B)

- Construction 705 lei $/ \mathrm{m}^{2}$ Ad

- Electric equipment $23 \mathrm{lei} / \mathrm{m}^{2} \mathrm{Ad}$

- Sanitary equipment 72 lei $/ \mathrm{m}^{2} \underline{\mathrm{Ad}}$

Total construction + equipment 800 lei $/ \mathrm{m}^{2} \mathrm{Ad}$

Total basic value for construction and equipment :

$208,89 \mathrm{~m}^{2} \times 800 \mathrm{lei} / \mathrm{m}^{2} \mathrm{Ad}=167.112$ lei

Adjustments :

- For heights more than $2,80 \mathrm{ml}$, we add $4 \%$ of the value

$$
167.112 \text { lei } x \%=+\quad 6.684 \text { lei }
$$

- Tinplate roofing : $252 \mathrm{mp}$ x $15 \mathrm{lei} / \mathrm{mp} / \mathrm{Ad}=+3.780$ lei

- Gaswarming for tilestovesla: $77,79 \mathrm{mp}$ x 28 lei $/ \mathrm{mp} / \mathrm{Ad} \equiv+\quad 2.178$ lei

TOTAL ADJUSTMENT

Total adjusted basic value: 167.112 lei +12.642 lei $=179.754$ lei

Actualization coefficient: 28.771,957, according to "ExpertizaTehnica" 107/ May 2019, periodical, of whichweremove the VAT;

179.754 lei x 28.771,957 / 10.000/ 1,19=434.611 lei

Total replacement value for house: 434.611lei

The basic unitary value according to the catalogue no 124, file no. 11 is $530 \mathrm{lei} / \mathrm{m}^{2}$ Ad for brick buildings and $65 \mathrm{lei} / \mathrm{m}^{2} \mathrm{Ad}$ for wooden constructions.
$36,35 \mathrm{mp} \times 530 \mathrm{lei} / \mathrm{m}^{2} \mathrm{Ad}=$
$6,76 \mathrm{mp} \times 365 \mathrm{lei} / \mathrm{m}^{2} \mathrm{Ad}=$
+19.266 lei
+2.467 lei
Total basic value:
21.733 lei

\section{Adjustments :}

- For heights lower than $2,80 \mathrm{ml}$, minus $4 \%$ of the value

- for lack of finish, minus 90 lei $/ \mathrm{m}^{2}$

$$
21.733 \text { lei } \times 14 \% \quad=-3.043 \text { lei }
$$

$$
(36,35+6,76) \times 90 \text { lei/mp } \quad \equiv-3.880 \text { lei }
$$

Total corrections

$$
=-6.923 \text { lei }
$$

Total adjusted basic value: 21.733 lei -6.923 lei $=11.354$ lei

Actualization coefficient: 28.771,957, according to "ExpertizaTehnica" 107/ May 2019, periodical, minus TVA ;

Total replacement value: 11.354 lei x 28.771,957 / $10.000 / 1,19=\mathbf{2 7 . 4 5 2 1 e i}$

Total replacement value is : 27.452 lei

Total value withoutdepreciation of the building : 434.611 lei +27.452 lei $=\mathbf{4 6 2 . 0 6 3}$ lei

"the new value", whichis set on the free market for similar buildings, withspecialequipment, withoutdepreciation, calculated for the threecurrenciesis:

\subsection{LEI}

\subsection{EUR}

3.The estimation of the replacement value of the building through the estimation method

According to the "Technical guide for the immediate evaluation of the spot price, of the costs of the elements and the house constructions - percentage and value", issued by MATRIX ROM, the evaluated building was classified as "Individual house in the urban environment, increased comfort, having all facilities, gas stoves, tin roofing, wooden floor". 


\section{Estimation of the building -Table no:1}

\begin{tabular}{|c|c|c|c|c|c|c|c|}
\hline \multirow{2}{*}{$\begin{array}{l}\text { Nr. } \\
\text { crt }\end{array}$} & \multirow{2}{*}{$\begin{array}{l}\text { Name of the } \\
\text { process }\end{array}$} & \multirow{2}{*}{ UM } & \multirow{2}{*}{$\begin{array}{l}\text { Quant } \\
/ \mathrm{mp} / \mathrm{A} \\
\mathrm{d}\end{array}$} & \multicolumn{3}{|c|}{ Unit cost in lei } & \multirow{2}{*}{$\begin{array}{l}\text { Percentag } \\
\text { e of total }\end{array}$} \\
\hline & & & & $\mathbf{U M}$ & Mp Ad & $\mathbf{M p ~ A u}$ & \\
\hline 1 & Excavation & Mc & 0,5030 & 342000 & 172026 & 274764 & 0,8908 \\
\hline 2 & $\begin{array}{l}\text { Filling and } \\
\text { compacting }\end{array}$ & Mc & 0,1640 & 131600 & 21582 & 34471 & 0,1118 \\
\hline 3 & $\begin{array}{l}\text { Hydrois and similar } \\
\text { work }\end{array}$ & $\mathrm{Mp}$ & 0,3490 & 976000 & 340624 & 544052 & 1,7638 \\
\hline 4 & Reinforced concrete & Mc & 0,2100 & $\begin{array}{r}938300 \\
0 \\
\end{array}$ & $\begin{array}{r}197043 \\
0 \\
\end{array}$ & $\begin{array}{r}314721 \\
5 \\
\end{array}$ & 10,2030 \\
\hline 5 & Concrete & $\mathrm{Mc}$ & 0,3900 & $\begin{array}{r}237200 \\
0\end{array}$ & 925080 & $\begin{array}{r}147755 \\
8 \\
\end{array}$ & 4,7901 \\
\hline 6 & Masonry & Mc & 0,6860 & $\begin{array}{r}436550 \\
0 \\
\end{array}$ & $\begin{array}{r}299473 \\
3 \\
\end{array}$ & $\begin{array}{r}478325 \\
4 \\
\end{array}$ & 15,5069 \\
\hline 7 & $\begin{array}{l}\text { Closings } \\
\text { Segmentation.. }\end{array}$ & $\mathrm{Mp}$ & 0,650 & 529000 & 34385 & 54920 & 0,1780 \\
\hline 8 & Metal works & $\mathrm{Kg}$ & 1,8500 & 75000 & 138750 & 221615 & 0,7185 \\
\hline 9 & $\begin{array}{ll}\text { Thermois } & \text { attic } \\
\text { protection }\end{array}$ & $\mathrm{Mp}$ & 0,9230 & 405000 & 373815 & 597066 & 1,9356 \\
\hline 10 & Thermoispipes & $\mathrm{Mp}$ & 0,0150 & 389000 & 5835 & 9320 & 0,0302 \\
\hline 11 & Woodwork & $\mathrm{Mp}$ & 0,2300 & $\begin{array}{r}570850 \\
0 \\
\end{array}$ & $\begin{array}{r}131295 \\
5 \\
\end{array}$ & $\begin{array}{r}209708 \\
1 \\
\end{array}$ & 6,7986 \\
\hline 12 & PVC work & $\mathrm{Mp}$ & 0,1280 & $\begin{array}{r}301300 \\
0 \\
\end{array}$ & 385664 & 615991 & 1,9970 \\
\hline 13 & Metalwork & $\mathrm{Kg}$ & 2,0000 & 90000 & 180000 & 287500 & 0,9321 \\
\hline 14 & Simple windows & $\mathrm{Mp}$ & 0.0240 & 253600 & 6086 & 8721 & 0,0315 \\
\hline 15 & $\begin{array}{ll}\begin{array}{l}\text { Double } \\
\text { windows }\end{array} & \text { insulated } \\
\end{array}$ & $\mathrm{Mp}$ & 0,2560 & $\begin{array}{r}167300 \\
0\end{array}$ & 428288 & 684071 & 2,2177 \\
\hline 16 & $\begin{array}{l}\text { Reinforced } \\
\text { windows }\end{array}$ & $\mathrm{Mp}$ & 0,0260 & 488000 & 12688 & 20266 & 0,0657 \\
\hline 17 & Mosaic flooring & $\mathrm{Mp}$ & 0,0430 & $\begin{array}{r}116300 \\
0 \\
\end{array}$ & 50009 & 79875 & 0,2589 \\
\hline 18 & oncrete flooring & $\mathrm{Mp}$ & 0,1700 & 408000 & 69360 & 110783 & 0,3591 \\
\hline 19 & Tile flooring & $\mathrm{Mp}$ & 0,2000 & 919000 & 183800 & 293569 & 0,9517 \\
\hline 20 & Parquet flooring & $\mathrm{Mp}$ & 0,3830 & 943000 & 361169 & 576867 & 1,8702 \\
\hline 21 & Internal stucco & $\mathrm{Mp}$ & 4,300 & 384000 & $\begin{array}{r}165120 \\
0 \\
\end{array}$ & $\begin{array}{r}263733 \\
3 \\
\end{array}$ & 8,5500 \\
\hline 22 & Interior paint job & $\mathrm{Mp}$ & 3,4600 & 89600 & 310016 & 495164 & 1,6053 \\
\hline 23 & Wall tiles job & $\mathrm{Mp}$ & 0,2460 & 912700 & 224524 & 358615 & 1,1626 \\
\hline 24 & Interior paintings & $\mathrm{Mp}$ & 0,4200 & 139000 & 58380 & 93246 & 0,3023 \\
\hline 25 & external stucco & $\mathrm{Mp}$ & 0,8210 & 717700 & 589232 & 941134 & 3,0511 \\
\hline 26 & External tilling & $\mathrm{Mp}$ & 0,6160 & $\begin{array}{r}136500 \\
0\end{array}$ & 840840 & $\begin{array}{r}134300 \\
8\end{array}$ & 4,3539 \\
\hline 27 & Concrete sidewalk & $\mathrm{Mp}$ & 0,2670 & 342000 & 91314 & 145849 & 0,4728 \\
\hline 28 & Framing & $\mathrm{Mp}$ & 0,9230 & 428000 & 395044 & 630973 & 2,0456 \\
\hline 29 & Roofing, sheathing & $\mathrm{Mp}$ & 1,1350 & 666000 & 755910 & $\begin{array}{r}120735 \\
6 \\
\end{array}$ & 3,9142 \\
\hline 30 & $\begin{array}{ll}\text { Gutters } & \text { and } \\
\text { drainpipes } & \\
\end{array}$ & $\mathrm{Ml}$ & 0,2670 & 424000 & 113208 & 180818 & 0,5862 \\
\hline 31 & Clogged eave & $\mathrm{Mp}$ & 0,1330 & 427000 & 56791 & 90708 & 0,2941 \\
\hline
\end{tabular}


International Conference "Risk in Contemporary Economy" ISSN-L 2067-0532 ISSN online 2344-5386

$\mathrm{XX}^{\text {th }}$ Edition, 2019, Galati, Romania,

"Dunarea de Jos" University of Galati, Romania - Faculty of Economics and Business Administration

\begin{tabular}{|c|c|c|c|c|c|c|c|}
\hline 32 & $\begin{array}{l}\text { Snuff boxes and } \\
\text { ventilation }\end{array}$ & $\mathrm{Mp}$ & 0,0240 & 923000 & 18460 & 29485 & 0,0956 \\
\hline 33 & Stoves & Cahle & 3,0000 & 168900 & 506700 & 809313 & 2,6237 \\
\hline 34 & $\begin{array}{l}\text { Other works and } \\
\text { constructions }\end{array}$ & $\%$ & 3,0000 & 0 & 471976 & 753851 & 2,4201 \\
\hline 32 & Water branching & Lei & 1,0000 & 506100 & 506100 & 808354 & 2,6206 \\
\hline 33 & $\begin{array}{l}\text { Sanitary pipes and } \\
\text { joints }\end{array}$ & $\mathrm{Ml}$ & 0,5130 & 342300 & 175600 & 280472 & 0,9093 \\
\hline 34 & $\begin{array}{l}\text { Sanitary equip. and } \\
\text { reinforcement }\end{array}$ & Lei & 1,0000 & 536800 & 536800 & 857389 & 2,7796 \\
\hline 35 & Electric boiler & Lei & 1,0000 & 144900 & 144900 & 231438 & 0,7503 \\
\hline 36 & $\begin{array}{l}\text { Electricity } \\
\text { branching }\end{array}$ & Lei & 1,0000 & 106000 & 106000 & 169306 & 0,5489 \\
\hline 37 & $\begin{array}{l}\text { Electric cable, cond, } \\
\text { pipes }\end{array}$ & $\mathrm{Ml}$ & 3,0500 & 70000 & 213500 & 341007 & 1,1055 \\
\hline 38 & Electric equipment & Lei & 1,0000 & 172200 & 172200 & 275042 & 0,8917 \\
\hline 39 & Lighting devices & Lei & 1,0000 & 117200 & 117200 & 187194 & 0,6059 \\
\hline 40 & Gas branching & Lei & 1,0000 & 305700 & 305700 & 488271 & 1,5829 \\
\hline 41 & $\begin{array}{l}\text { Other common } \\
\text { equipment }\end{array}$ & $\%$ & 3,0000 & 0 & 68340 & 109154 & 0,3539 \\
\hline \multirow[t]{3}{*}{42} & $\begin{array}{l}\text { Various, } \\
\text { organization, }\end{array}$ & $\%$ & 5,0000 & 0 & 919630 & $\begin{array}{r}145885 \\
3 \\
\end{array}$ & 4,7619 \\
\hline & Total lei/mp & & & & $\begin{array}{r}193122 \\
35 \\
\end{array}$ & $\begin{array}{r}308459 \\
30 \\
\end{array}$ & 100 \\
\hline & TOTAL EUR/mp & & & & $\begin{array}{r}568,01 \\
\text { EUR/ } \\
\mathrm{mp} \\
\end{array}$ & $\begin{array}{r}907,23 \\
\text { EUR/ } \\
\text { mp }\end{array}$ & \\
\hline
\end{tabular}

Table no.2 Evaluation (outbuildings)

\begin{tabular}{|c|c|c|c|c|c|c|c|}
\hline \multirow[b]{2}{*}{$\begin{array}{l}\text { Nr. } \\
\text { crt }\end{array}$} & \multirow[b]{2}{*}{ Process name } & \multirow[b]{2}{*}{ MU } & \multirow{2}{*}{$\begin{array}{l}\text { Quantit } \\
\text { y/mp/ } \\
\text { Ad }\end{array}$} & \multicolumn{3}{|c|}{ Unit costs in lei per } & \multirow[b]{2}{*}{$\%$ of total } \\
\hline & & & & MU & Mp Ad & $\begin{array}{l}\mathrm{Mp} \\
\mathrm{Au}\end{array}$ & \\
\hline 1 & Easy foundation & Mc & 0,2600 & $\begin{array}{r}132700 \\
0 \\
\end{array}$ & 345020 & 0 & 9,1418 \\
\hline 2 & Brick constructions & Mc & 0,3500 & $\begin{array}{r}326750 \\
0\end{array}$ & 1143625 & 0 & 30,3021 \\
\hline 3 & windows & $\mathrm{Mp}$ & 0,1000 & 227000 & 22700 & 0 & 0,6015 \\
\hline 4 & Internal stucco & $\mathrm{Mp}$ & 1,9000 & 170000 & 323000 & 0 & 8,5584 \\
\hline 5 & External stucco & $\mathrm{Mp}$ & 2,8000 & 11900 & 33320 & 0 & 0,8829 \\
\hline 6 & External smattering & $\mathrm{Mp}$ & 1,5000 & 11900 & 17850 & 0 & 0,4730 \\
\hline 7 & Carpentry painting & $\mathrm{Mp}$ & 0,8000 & 78500 & 62800 & 0 & 1,6640 \\
\hline 8 & External plaster & $\mathrm{Mp}$ & 1,5000 & 268000 & 402000 & 0 & 106516 \\
\hline 9 & Simple windows & $\mathrm{Mp}$ & 0,1000 & 999000 & 99900 & 0 & 2,6470 \\
\hline 10 & Simple doors & $\mathrm{Mp}$ & 0,2000 & $\begin{array}{r}122450 \\
0 \\
\end{array}$ & 244900 & 0 & 6,4890 \\
\hline 11 & Ceiling finish & $\mathrm{Mp}$ & 1,0000 & 264000 & 264000 & 0 & 6,9951 \\
\hline 12 & framing & $\mathrm{Mp}$ & 1,2000 & 294000 & 352800 & 0 & 9,3480 \\
\hline 13 & Tin roofing & $\mathrm{Mp}$ & 1,2000 & 216000 & 259200 & 0 & 6,8679 \\
\hline 14 & Wooden sheathing & $\mathrm{Mp}$ & 1,2000 & 138000 & 165600 & 0 & 4,3878 \\
\hline 15 & Various & $\%$ & 1,0000 & 0 & 37367 & 0 & 0,9901 \\
\hline
\end{tabular}




\begin{tabular}{|r|l|l|l|r|r|r|r|}
\hline & TOTAL lei/mp & & & & 3.774 .082 & & 100 \\
\hline & TOTAL EUR/mp & & & & 121,00 & & \\
\hline
\end{tabular}

The reconstruction cost in EUR is :

Hous :

208,89mp x 568,01 EUR/mpAd= 118.652 EUR

The reconstruction value in LEI at the date of the evaluation(1 EUR $=4,73 \mathrm{LEI})$ is :

118.652EUR x 4,73 LEI/EUR = 561.223 LEI

43,11 $\mathrm{mp} \times 121,00 \mathrm{EUR}=\mathbf{5 . 2 1 6}$ EUR, The reconstruction value in lei at the date of the evaluation: 5.216 EUR x 4,73 LEI/EUR = 24.671 LEI

Total value: $561.223 \mathrm{LEI}+24.671 \mathrm{LEI}=585.894 \mathrm{LEI}$

The unitarycomparisonmethod - the unit scale (catalogue) cost and the estimation method has allowed the reaching of close results for the construction that made the subject of evaluation:

Table no .3 Resulted values

\begin{tabular}{|l|l|l|}
\hline \multirow{2}{*}{ Appliedmethods } & \multicolumn{2}{|l|}{ Resulted values } \\
\cline { 3 - 4 } & LEI & EUR \\
\hline $\begin{array}{l}\text { The catalogue value } \\
\text { method }\end{array}$ & 462.063 & $\mathbf{9 7 . 6 8 7}$ \\
\hline Estimation method & $\mathbf{5 8 5 . 8 9 4}$ & $\mathbf{1 2 3 . 8 6 8}$ \\
\hline
\end{tabular}

\section{Conclusions}

Considering that the estimation methodis the most complete and accurate method, the result reached through this methodis the closest one to the market value, namely: 462.063 LEI; respectively $97.687 \mathbf{E U R}$;

\section{Segregation method}

This method assumes that the evaluator is to individually analyze each cause of depreciation, to quantify it and to calculate a global amount.

The five types of depreciation, which can influence a building, are:

The recoverable physical attrition - only refers to the elements that must be repaired at the moment of evaluation and is quantified through the cost of bringing the product to the status of new. The attrition is seen as recoverable when the cost for the correcting of its technical status plus a reasonable profit is lower than the resulted value growth.

Unrecoverable physical attrition - aims at the physically damaged elements which cannot be currently repaired due to practical or economic reasons. Unrecoverable physical attrition applies on the difference between the reconstruction or replacement cost and the removal cost of the recoverable physical attrition. The elements of the unrecoverable physical attrition are qualified as having a short or a long life.

A short life element is the one with a remaining economic life span lower than the remaining economic life span of the whole building.

A long life element is a component of the building which is expected to have the same remaining life span as the whole building.

The functional recoverable inadequacy - represents a value loss due to the deficiencies in the conception or projecting of the building. In order to be recoverable, the replacement cost of an outmoded or inacceptable issue must be lower than the anticipated value growth.

The functional unrecoverable inadequacy - can be caused by a deficiency or by oversizing. 
Two types of deficiencies can be applied: an element that is not included in the new cost, but which must be included or an element that is included in the new cost, but which shouldn't have been included.

The external (economic) causes depreciation - is the diminished utility of a building due to some negative influences from the external environment of the building. It can be caused by a series of factors, such as: the decrease of the proximity, the location of the propriety in the locality, region or province, the conditions of the local market.

\section{Physical attrition}

- PIF - 1920

- 83 years old

- Good technical condition- attrition coefficient according. P 13-199.

- According to the data and observations in the field, of the fact that the building has been repaired subsequently to every earthquake through time, of the improvements and the modernization of the comfort degree, the value of the depreciation degree is estimated at:

Table no:4

\begin{tabular}{|l|c|c|c|}
\hline \multicolumn{1}{|c|}{ Subassembly name } & percentage & $\begin{array}{c}\text { Estimated } \\
\text { attrition }\end{array}$ & $\begin{array}{c}\text { Average } \\
\text { attrition }\end{array}$ \\
\hline Protective structure & $40 \%$ & $75 \%$ & $30 \%$ \\
\hline envelope & $17 \%$ & $65 \%$ & $11,50 \%$ \\
\hline Finish & $25 \%$ & $60 \%$ & $15,50 \%$ \\
\hline equipment & $18 \%$ & $40 \%$ & $7,20 \%$ \\
\hline Total & $100 \%$ & & $\mathbf{6 4 , 2 0 \%}$ \\
\hline
\end{tabular}

Considering the presented data, I assume that the depreciation degree is $64,20 \%$, according to the standards and the observations in the field, at the moment of the inspection, as being the real depreciation degree; given, the Cumulated Depreciation will reach 462.063x 0,6420 = 296.644 LEI. The value of the constructions, depreciated, willbe : 462.063LEI - 296.644 LEI = 165.419 LEI

The value of the case building (terrain and construction) determinedthrough the costmethodisequal to the amount of the evaluated values for:

- terrain :

331.664 LEI

- construction :

165.419 LEI

TOTAL :

497.083 LEI

The value of the building, reachedthrough the " costmethod ", without VAT is:

$$
\begin{gathered}
=417.717 \text { LEI } \\
=88.312 \text { EUR }
\end{gathered}
$$

Conclusions

The evaluator must not mistake the depreciation concept from the perspective of the evaluation for the accounting deprectiation concept, which refers to the amortisation of the tangleassets. The estimation method of the new cost and of the depreciation must be presented in the evaluation report, alongside the arguments that layat the basis of its calculus. The use of other depreciation form sisforbidden, if their estimation methodcannotbepresented.

\section{References}

1. Andreica H.-A., Vereș D., Evaluare Imobiliară, Editura U.T. Pres, Cluj-Napoca, 2002

2. Bologa A., Evaluarea intreprinderii, Editura CIBERNETICA MC, București, 2011

3. Crivii Adrian, Vascu Adrian - "Evaluarea intreprinderilor - curs -" ed. a V-a, Biblioteca ANEVAR, 1999

4. Deaconu A., Evaluarea afacerilor, Editura Intelcredo, Deva, 2002

5. Deaconu A., Diagnosticul și evaluarea afacerii, Suport de curs 2012-2013, Cluj- Napoca, 2012 
6. Frăsineanu, C., Metode de evaluare a patrimoniului,Editura ASE, București, 2002

7. Goagară D.,Giurcă-V asilescu L., Evaluation based on assets: critical analysis,Universitatea din Craiova, 2009

8. Iancu D., Managerial Leadership From The Perspective Of Environment Organizational Sports, International Conference Of Scientific Paper Afases 2012 Brasov, 24-26 May 2012;

9. Iancu D., Educational Management, A New Paradigm In Social Development, International Conference Of Scientific Paper Afases 2012 Brasov, 24-26 May 2012;

10. Lungu I., Komartin R., Justificarea financiară a investițiilor informatic, RevistaInformatica Economica, nr.2, vol. 14: 44, 2010

11. Matiș D., Timbruș R., Buglea A., Oprean V.B., Evaluarea proprietatilor imobiliare, Editura Risoprint, Cluj-Napoca, 2013

12. Morariu A., Crecană C.D.,Investițiile imobiliare din România - analiză și tendințe, Analiza economicofinanciară și evaluarea proprietăților, Simpozion Științific, 2009

13. Popescu C., Asmarandei A., Standarde privind Evaluarea Proprietății ,Revista Română de Statistică, Trim 3/2012

14. Shannon P. Pratt, Abordarea prin piață a evaluării proprietății imobiliare

15. Stan V., Anghel I., (coord.) - Evaluarea intreprinderii, Editia a treia revizuita, Editura IROV AL 2007;

16. Vascu A., Evaluarea proprietătilor imobiliare, Suport de cu 